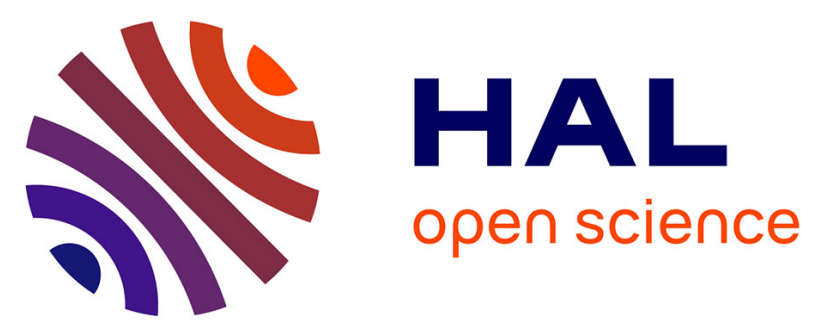

\title{
Sex differences in cigarette brand purchases among adult smokers: results from the DePICT national repeated survey of French adults (2016-2017)
}

Fabienne El-Khoury Lesueur, Hugo Torregrossa, Ramchandar Gomajee, Camille Bolze, Maria Melchior

\section{To cite this version:}

Fabienne El-Khoury Lesueur, Hugo Torregrossa, Ramchandar Gomajee, Camille Bolze, Maria Melchior. Sex differences in cigarette brand purchases among adult smokers: results from the DePICT national repeated survey of French adults (2016-2017). European Journal of Health Economics, 2021, 22 (2), pp.223-228. 10.1007/s10198-020-01244-2 . hal-03146787

\section{HAL Id: hal-03146787 \\ https://hal.sorbonne-universite.fr/hal-03146787}

Submitted on 19 Feb 2021

HAL is a multi-disciplinary open access archive for the deposit and dissemination of scientific research documents, whether they are published or not. The documents may come from teaching and research institutions in France or abroad, or from public or private research centers.
L'archive ouverte pluridisciplinaire HAL, est destinée au dépôt et à la diffusion de documents scientifiques de niveau recherche, publiés ou non, émanant des établissements d'enseignement et de recherche français ou étrangers, des laboratoires publics ou privés. 


\title{
Sex-differences in cigarette brand purchases
}

\author{
among adult smokers. Results from the DePICT
}

national repeated survey of French adults (2016-

$$
\text { 2017). }
$$

\begin{abstract}
Objective

The tobacco industry has been reported to employ sex-specific marketing strategies, which include different types of tobacco packaging, publicity, as well as price strategies. We examined whether characteristics associated with the purchase of more expensive cigarette brands varied between the two sexes, in the context of the introduction of plain tobacco packaging and the strengthening of tobacco control policies in France.
\end{abstract}

\section{Methods}

Our study population consists of 1380 regular smokers of manufactured cigarettes from the DePICT study, a nation-wide two-wave survey of French adults aged 18 to 64 years.

Participants were interviewed by telephone in 2016 and 2017. Factors associated with the use of more vs. less expensive cigarette brands were determined by multivariable logistic regression for each sex.

Results

Several sex-specific factors were associated with the purchase of more expensive cigarette brands. In women, those factors included higher education, cannabis use, and no use of roll- 
your-own tobacco. While in men purchase of more expensive cigarette brands was linked to younger age, being born outside of France, living with a non-smoker, and attachment to the cigarette brand.

\section{DISCUSSION}

Factors which predict tobacco purchase patterns are different in women and men, highlighting the need for sex-specific tobacco control initiatives to counter the tobacco industry's gendered marketing.

\section{KEY WORDS}

Smoking, tobacco packaging, sex differences, tobacco control. 


\section{INTRODUCTION}

Globally, smoking uptake and cessation are marked by sex-differences, men being more likely to smoke than women [1]. Nonetheless, this sex difference has been decreasing, especially in high income countries, which partly reflects the tobacco industry's gendersensitive and specific marketing [2]. Today, the tobacco industry employs particular features such as slim cigarettes, "lighter" tastes (i.e. menthols ...), and "glamorous" and positive names to attract women to smoking [3]. The sale of these products, at premium prices, reinforces this "stylish" image associated with smoking, and might explain why young women appear to be less responsive to cigarette price increases than young men [4]. These sex differences in tobacco-related behaviors have resulted in calls for systematic gender analyses in studies of tobacco-related behaviors [5].

Increases in taxes and the price of tobacco products have been proven to be effective tobacco control measures [6]. It has also been argued that price increases are the most effective measure to curb the prevalence of tobacco smoking. In France, several tobacco control measures have been recently implemented, notably a 5 to $5.5 \%$ increase in taxing resulting in an increase in tobacco price in November 2017, along with announcement of several future tobacco price increases [7]. Moreover, from January $1^{\text {st }} 2017$, the French government introduced plain packaging of tobacco products, and therefore all tobacco products sold in France are now presented in standardised dark-grey packs with uniform font. This intensification in the tobacco control policies has coincided with the first decrease in smoking rates among adults in France in decades [8]. Between 2016 and 2017, daily smoking rates unprecedentedly dropped by $3 \%$ [9].

One of the methods used by the tobacco industry to counter such tobacco control measures is 
the introduction of low-priced cigarette brands and the widening of the gap between the least and most expensive cigarette brands, so that more socially disadvantaged smokers can downtrade to cheaper tobacco products [10].

In fact, some tobacco brands' "prestige" is reinforced by a relatively more expensive price range of their sub-brands. For example, in 2017, the price of different Marlboro sub-types (“Red","Beyond Blue Ice","Gold",...) was always at least 7€. Whereas, the less expensive popular brand "News" was sold in different sub-types ("Classic Red","Fortuna",...) for less than $6.7 €$.

We studied factors associated with the purchase of more expensive cigarette brands separately in men and women. Specifically, we sought to test whether socio-demographic characteristics such as age and educational attainment are similarly associated with the price spent on cigarette purchases in men and women.

We use data from a two-wave cross-sectional study that took place concomitantly with an intensification of tobacco control measures and a drop in smoking rates among adults in France.

\section{METHODS}

\section{DePICT: study design and recruitment}

We use data from DePICT (Description des Perceptions, Images, et Comportements liés au Tabagisme), a nationwide repeat cross-sectional telephone survey of adults (18-64 years) residing in mainland France. DePICT received approval of the ethical review committee of the French National Institute of Health and Medical Research (INSERM, CEEI-IRB 00003888). 
Participants were recruited via a computer-assisted telephone interview (CATI) system and interviewed via landline or mobile telephone between August 15 and November 15, 2016 and 2017.Telephone lists were randomly generated and cross-checked to remove false or professional numbers. This method has the advantage of including both listed and unlisted phone numbers and therefore provides maximum population representativeness. All phone numbers were dialed up to 30 times in different periods of the day and week. In households reached by landline, one participant was randomly selected by the CATI system (Kish method). In total we had recruited 4456 adults in 2016 (response rate =63\%), and 4114 adults in 2017 (response rate $=50 \%$ ), using a simple random sampling.

\section{Study Interview}

Telephone interviews (average duration: $25 \mathrm{~min}$ ) were conducted by 30 trained interviewers who administered the questionnaire from a call center equipped with computerized telephone stations. After a brief description of study aims and participants' verbal consent, data were collected on: demographics, smoking status, smoking-related behaviors and perceptions.

\section{Outcome variable and covariates}

\section{Cigarette brand price range}

Daily smokers of manufactured cigarettes were asked about their currently most used tobacco brand. This information was missing for 8 female and 10 male daily smokers who did not report having a favorite brand and were excluded from the analyses.

For each brand, using official listings published in November 2017, we extracted the price and change in price between November 2016 and November 2017 of the most frequently sold sub-type of cigarettes (i.e. "classic"/"red" or "light"/"blue", usually sold at the same price) [7] Using this information, we defined the binary study outcome as: 1) "less expensive brands" 
(6.3 to $6.6 €) ; 2$ ) "more expensive brands" (6.7 to $7.8 €)$. In supplementary data 1 , we present the price range for sub-types of popular brands as well as their classification.

\section{Characteristics associated with the cigarette brand purchases}

Covariates were selected based on prior studies identifying factors associated with tobacco purchases $[11,12]$. These included characteristics related to tobacco and other substance use, such as the number of cigarettes smoked daily $(0-10, \geq 10)$, household tobacco exposure (living alone, no, yes, partner or someone else than the partner), (at least occasional) smoking of roll-your-own tobacco (yes/no), and cannabis use in the preceding 12 months (yes/no). We also collected data on cross-border purchases of tobacco in the preceding year (yes/no), and attachment to the tobacco brand ("I favor this brand" completely agree vs. other). We also collected data on sociodemographic characteristics including sex, age, education level $(<$ high school degree / high school degree (French baccalaureate 'Bac') - a degree requiring 2 years of study after the baccalaureate (bac +2$) /$ a university degree $(\geq \mathrm{Bac}+3)$ ), birthplace (France /outside of France), and whether participants lived in the Parisian region (yes/no).

\section{Statistical analyses}

All analyses were stratified by sex to test whether factors associated with tobacco purchases vary in men and women. No sampling weights were used for this study. To identify factors that differentiate consumers of more vs. less expensive cigarette brands, we selected characteristics that were potentially associated with the outcome variable in bivariate analyses $(\mathrm{p}<0.2)$ and included them in a multivariable logistic regression model. All analyses were conducted using SAS 9.4. 


\section{RESULTS}

Participants' characteristics are described in Table 1. Smokers of more expensive cigarette brands accounted for $46.6 \%(n=321 / 689)$ of all female daily smokers compared to $58.6 \%$ ( $n=405 / 691)$ of male daily smokers. We observed a comparable rates of expensive brand purchase between the two waves $(52.7 \%$ in 2016 vs $50.8 \%$ in 2017 , p value (chi2) $=0.44$ ).

Table 2 shows the results of multivariable logistic models examining factors related to the purchase of more expensive compared to less expensive cigarette brands, stratified by sex. Rates of more expensive cigarette brands purchase did not vary between the two study waves (2016 and 2017). In women, factors associated with the purchase of more expensive cigarette brands included: smoking less than 10 cigarettes per day (OR=1.45, $95 \mathrm{CI}, 1.04-2.02)$, not smoking roll-your-own tobacco $(\mathrm{OR}=1.88,95 \mathrm{CI}, 1.17-3.02)$, cannabis use in the preceding 12 months $(\mathrm{OR}=3.03,95 \mathrm{CI}, 1.69-5.42)$, education level $(\mathrm{OR}$ university degree $=2.00,95 \%$ CI, 1.38-2.89, OR university degree +2 years $=2.09,95 \% \mathrm{CI}, 1.37-3.18)$ and residence in the Greater Paris region $(\mathrm{OR}=1.48,95 \% \mathrm{CI}, 1.00-2.19)$.

In men, factors associated with purchase of more expensive cigarette brands included: living in a non-smoking household $(\mathrm{OR}=1.83,95 \% \mathrm{CI}, 1.24-2.72)$, attachment to the brand of cigarettes currently used (OR=1.66, $95 \mathrm{CI}, 1.20-2.31)$, being 18-24 and 25-44 year-olds (OR $18-24$ years $=3.81,95 \% \mathrm{CI}, 2.05-7.09$, OR $25-44$ years $=1.91,95 \% \mathrm{CI}, 1.34-2.71)$ and not being born in France (OR=4.45, 95\% CI, 2.23-8.88). 


\section{DISCUSSION}

\section{Key Findings}

Studying a sample of French daily cigarettes smokers, we found no differences in the price of cigarettes purchased after the implementation of stricter tobacco control policies, which included plain packaging. Overall, women were more likely to report smoking lower price cigarette brands than men and factors associated with the type of cigarettes smoked varied between the two sexes. While in women, the purchase of more expensive cigarette brands was predicted by higher education, no roll-your-own tobacco use nor cannabis use, in men, being born outside of France, residence with a non-smoker, attachment to the brand and older age were associated with purchasing patterns. These findings suggest that in a context of strengthening tobacco control policies and price increases, a substantial fraction of smokers continue to purchase more expensive cigarettes, probably in relation to the image that these brands carry or long-standing habits.

\section{Interpretation}

A higher education level is only associated with the purchase of more expensive cigarette brands among women. This could be explained by a higher proportion of premium priced brands marketed to women.

The frequent co-occurrence of tobacco and cannabis use is widely documented [13]. However to our knowledge the link between cannabis use and purchasing patterns of cigarettes has never been investigated. A possible explanation of why recent cannabis use may be associated with smoking more expensive cigarettes among women could be peer influence, which appears to have gender-specific effects $[13,14]$. It is also possible that 
women who smoke more expensive cigarette brands are socially more advantaged and therefore have more disposable income to buy cannabis [15-17].

Additionally, occasional smoking of roll-your-own tobacco was inversely associated with the purchase of expensive cigarette brands among women. It is possible that the purchase of roll-your-own tobacco is a strategy to lower costs among those who usually buy less expensive cigarettes and care less about the "glamorous image" of smoking. Smoking of roll your own tobacco is not associated with the purchase of expensive cigarette brands among men, probably because of the absence of premium priced/ "popular" brands.

Among men, not being born in France was the most important factor predicting the purchase of more expensive cigarettes. This could be due to a limited choice of brands in the country of origin and/or more intense marketing strategies of some mainstream (usually more expensive) tobacco brands in countries with less developed tobacco control measures, resulting in early and lifelong loyalty. In fact, the one brand commonly used by a majority of male participants not born in France in our sample, is the most purchased brand worldwide. Other brands frequently smoked in France are less frequently sold in world regions most immigrants to France come from [18].

\section{Limitations:}

Our study has several limitations. First, it was framed as a survey on smoking-related perceptions and behaviors, which may have increased the likelihood of selection bias among smokers. However, associations between cigarette purchases and associated factors are likely valid. Another limitation is that we did not ask the name of the exact sub-brand which participants smoked, making it impossible to ascertain the exact price of the cigarettes purchased. Nonetheless, prices of different sub-brands are generally rather close, and our use of the most popular sub-brand to reprint the price range of the brand should limit bias. 
Moreover, other non-measured criteria, beside an expensive price, could also be an indicator of a "glamorous" brand. Further, our approach did not allow to explicitly test whether an examined factor was differentially important for male vs. female smokers (interaction test), even if our results indicate that some factors are linked in one sex and not the other. To our knowledge, this is the first study to investigate determinants of patterns of purchasing different price cigarette brands, by sex. This information is important to take into account when formulating anti-tobacco strategies, especially that the tobacco industry can initiate cigarette price changes to undermine tobacco control measures [10]

\section{CONCLUSION}

Our findings highlight sex-differences in cigarette purchasing among adult daily smokers in France, and the subsequent need for sex-specific initiatives in tobacco control efforts to counter the tobacco industry's gendered marketing. 


\section{REFERENCES}

1. Ng M, Freeman MK, Fleming TD, et al: Smoking prevalence and cigarette consumption in 187 countries, 1980-2012. JAMA. 311, 183-192 (2014). https://doi.org/10.1001/jama.2013.284692

2. Amos, A.: From social taboo to "torch of freedom": the marketing of cigarettes to women. Tobacco Control. 9, 3-8 (2000). https://doi.org/10.1136/tc.9.1.3

3. Castaldelli-Maia, J.M., Ventriglio, A., Bhugra, D.: Tobacco smoking: From 'glamour' to 'stigma'. A comprehensive review. Psychiatry and Clinical Neurosciences. 70, 24-33 (2016). https://doi.org/10.1111/pcn.12365

4. Rice, N., Godfrey, C., Slack, R., Sowden, A., Worthy, G.: A systematic review of the effects of price on the smoking behaviour of young people. 191

5. Amos, A., Greaves, L., Nichter, M., Bloch, M.: Women and tobacco: a call for including gender in tobacco control research, policy and practice. Tobacco Control. 21, 236-243 (2012). https://doi.org/10.1136/tobaccocontrol-2011-050280

6. Chaloupka, F.J., Straif, K., Leon, M.E.: Effectiveness of tax and price policies in tobacco control. Tobacco Control. 20, 235-238 (2011). https://doi.org/10.1136/tc.2010.039982

7. LegiFrance: Arrêté du 6 novembre 2017 modifiant l'arrêté du 24 juin 2016 portant homologation des prix de vente au détail des tabacs manufacturés en France, à l'exclusion des départements d'outre-mer, https://www.legifrance.gouv.fr/eli/arrete/2017/11/6/CPAD1727941A/jo/texte, (2017)

8. El-Khoury, F., Bolze, C., Gomajee, R., White, V., Melchior, M.: Lower smoking rates and increased perceived harm of cigarettes among French adults one year after comprehensive tobacco control measures. Drug and Alcohol Dependence. 201, 65-70 (2019). https://doi.org/10.1016/j.drugalcdep.2019.03.025

9. Pasquereau, A., Andler, R., Guignard, R., Richard, J.-B., Arwidson, P., Nguyen-Thanh, V.: La consommation de tabac en France : premiers résultats du baromètre santé 2017, (2018)

10. Gilmore, A.B., Tavakoly, B., Taylor, G., Reed, H.: Understanding tobacco industry pricing strategy and whether it undermines tobacco tax policy: the example of the UK cigarette market. Addiction. 108, 13171326 (2013). https://doi.org/10.1111/add.12159

11. Choi, K., Hennrikus, D., Forster, J., St. Claire, A.W.: Use of Price-Minimizing Strategies by Smokers and Their Effects on Subsequent Smoking Behaviors. Nicotine Tob Res. 14, 864-870 (2012). https://doi.org/10.1093/ntr/ntr300

12. Huang, J., Zheng, R., Chaloupka, F.J., Fong, G.T., Li, Q., Jiang, Y.: Chinese smokers' cigarette purchase behaviours, cigarette prices and consumption: findings from the ITC China Survey. Tobacco Control. 23, i67-i72 (2014). https://doi.org/10.1136/tobaccocontrol-2013-051057

13. Agrawal, A., Budney, A.J., Lynskey, M.T.: The co-occurring use and misuse of cannabis and tobacco: a review. Addiction. 107, 1221-1233 (2012). https://doi.org/10.1111/j.1360-0443.2012.03837.x

14. Cowie, G.A., Swift, E., Borland, R., Chaloupka, F.J., Fong, G.T.: Cigarette brand loyalty in Australia: findings from the ITC Four Country Survey. Tobacco Control. 23, i73-i79 (2014).

https://doi.org/10.1136/tobaccocontrol-2013-051071

15. Beck, F., Legleye, S., De Peretti, G.: L’alcool donne-t-il un genre ? Trav0..ail, genre et sociétés. $\mathrm{N}^{\circ} 15$, 141 (2006). https://doi.org/10.3917/tgs.015.0141

16. Geels, L.M., Vink, J.M., Beek, J.H. van, Bartels, M., Willemsen, G., Boomsma, D.I.: Increases in alcohol consumption in women and elderly groups: evidence from an epidemiological study. BMC Public Health. 13, 207 (2013). https://doi.org/10.1186/1471-2458-13-207

17. Legleye, S., Khlat, M., Beck, F., Peretti-Watel, P.: Widening inequalities in smoking initiation and cessation patterns: A cohort and gender analysis in France. Drug and Alcohol Dependence. 117, 233-241 (2011). https://doi.org/10.1016/j.drugalcdep.2011.02.004

18. Bernardini, J.: L'Afrique s'enfume, http://www.otaf.info/sites/default/files/documents/bernardini-1afrique-s-enfume.pdf, (2008) 
Table 1: characteristics of study participants (depict study, $n=1398,2016$ 2017): \% p-value

\begin{tabular}{|c|c|c|c|c|c|c|c|}
\hline \multirow{2}{*}{ Characteristics } & & \multicolumn{3}{|c|}{ Women $(n=689)$} & \multicolumn{3}{|c|}{ Men $(n=691)$} \\
\hline & & $\begin{array}{l}\text { Low- } \\
\text { priced } \\
\text { cigarette } \\
\text { brand } \\
(53.4 \%)\end{array}$ & $\begin{array}{c}\text { More } \\
\text { expensive } \\
\text { cigarette } \\
\text { brand } \\
(46.6 \%)\end{array}$ & $\begin{array}{l}\mathrm{p}- \\
\text { value }\end{array}$ & $\begin{array}{c}\text { Low- } \\
\text { priced } \\
\text { cigarette } \\
\text { brand } \\
(41.4 \%)\end{array}$ & $\begin{array}{c}\text { More } \\
\text { expensive } \\
\text { cigarette } \\
\text { brand } \\
(58.6 \%)\end{array}$ & $\begin{array}{l}\mathrm{p}- \\
\text { Value }\end{array}$ \\
\hline \multirow{2}{*}{$\begin{array}{l}\text { Year of } \\
\text { investigation }\end{array}$} & 2016 & $58.4 \%$ & $61.4 \%$ & 0.43 & $55.9 \%$ & $58.3 \%$ & \multirow{2}{*}{0.54} \\
\hline & 2017 & $41.6 \%$ & $38.6 \%$ & & $44.1 \%$ & $41.7 \%$ & \\
\hline \multicolumn{8}{|l|}{$\begin{array}{l}\text { Tobacco and } \\
\text { other substance } \\
\text { use }\end{array}$} \\
\hline \multirow{2}{*}{$\begin{array}{l}\text { Number of } \\
\text { cigarettes per day }\end{array}$} & 0-9 cig/days & $32.9 \%$ & $42.7 \%$ & \multirow{2}{*}{0.01} & $23.1 \%$ & $27.2 \%$ & \multirow{2}{*}{0.22} \\
\hline & $\geq 10 \mathrm{cig} /$ days & $67.1 \%$ & $57.3 \%$ & & $76.9 \%$ & $72.8 \%$ & \\
\hline \multirow{3}{*}{$\begin{array}{l}\text { Household } \\
\text { tobacco exposure }\end{array}$} & Living alone & $39.4 \%$ & $38.6 \%$ & \multirow{3}{*}{0.97} & $41.3 \%$ & $32.8 \%$ & \multirow{3}{*}{0.02} \\
\hline & $\begin{array}{l}\text { Non-smoking } \\
\text { home }\end{array}$ & $28.3 \%$ & $28.4 \%$ & & $26.9 \%$ & $36.8 \%$ & \\
\hline & $\begin{array}{l}\text { Living with a } \\
\text { smoker (partner } \\
\text { or other) }\end{array}$ & $32.3 \%$ & $33.0 \%$ & & $31.8 \%$ & $30.4 \%$ & \\
\hline \multirow{2}{*}{$\begin{array}{l}\text { (At least } \\
\text { occasional) use of } \\
\text { roll-your-own } \\
\text { tobacco }\end{array}$} & No & $82.1 \%$ & $87.5 \%$ & \multirow[b]{2}{*}{0.05} & $78.7 \%$ & $78.3 \%$ & \multirow[b]{2}{*}{0.90} \\
\hline & Yes & $17.9 \%$ & $12.5 \%$ & & $21.3 \%$ & $21.7 \%$ & \\
\hline \multirow{2}{*}{$\begin{array}{l}\text { Cannabis smoked } \\
\text { in the past } 12 \\
\text { months }\end{array}$} & No & $94.0 \%$ & $85.1 \%$ & \multirow{2}{*}{0.00} & $86.0 \%$ & $76.8 \%$ & \multirow{2}{*}{0.00} \\
\hline & Yes & $6.0 \%$ & $15.0 \%$ & & $14.0 \%$ & $23.2 \%$ & \\
\hline \multicolumn{8}{|c|}{$\begin{array}{l}\text { Purchasing behavior and } \\
\text { perception of tobacco brand }\end{array}$} \\
\hline \multirow{2}{*}{$\begin{array}{l}\text { Cross-border } \\
\text { tobacco purchase }\end{array}$} & No & $58.7 \%$ & $61.1 \%$ & \multirow{2}{*}{0.53} & $62.9 \%$ & $55.6 \%$ & \multirow{2}{*}{0.05} \\
\hline & Yes & $41.3 \%$ & $38.9 \%$ & & $37.1 \%$ & $44.4 \%$ & \\
\hline \multirow{2}{*}{$\begin{array}{l}\text { Attachment to the } \\
\text { tobacco brand }\end{array}$} & Yes & $50.0 \%$ & $55.1 \%$ & \multirow{2}{*}{0.18} & $41.6 \%$ & $56.1 \%$ & \multirow{2}{*}{0.01} \\
\hline & No & $50.0 \%$ & $44.9 \%$ & & $15.4 \%$ & $44.0 \%$ & \\
\hline \multicolumn{8}{|c|}{ Sociodemographic characteristics } \\
\hline \multirow{3}{*}{ Age } & $18-24$ & $12.5 \%$ & $12.2 \%$ & \multirow{3}{*}{0.01} & $6.6 \%$ & $14.6 \%$ & \multirow{3}{*}{$<.0001$} \\
\hline & $25-44$ & $31.5 \%$ & $42.4 \%$ & & $38.8 \%$ & $49.1 \%$ & \\
\hline & $45-64$ & $56.0 \%$ & $45.5 \%$ & & $54.6 \%$ & $36.3 \%$ & \\
\hline \multirow{3}{*}{ Education level } & $\begin{array}{l}<\text { High school } \\
\text { degree }\end{array}$ & $44.7 \%$ & $26.5 \%$ & & $40.6 \%$ & $39.5 \%$ & \\
\hline & $\begin{array}{c}\text { High school } \\
\text { degree }-\mathrm{Bac}+2\end{array}$ & $35.2 \%$ & $43.0 \%$ & $<.0001$ & $39.2 \%$ & $40.5 \%$ & 0.94 \\
\hline & $\begin{array}{c}\geq \text { University } \\
\text { degree }(\geq \text { Bac } \\
+3)\end{array}$ & $20.2 \%$ & $30.5 \%$ & & $20.3 \%$ & $20.0 \%$ & \\
\hline Born in France & Yes & $91.6 \%$ & $92.2 \%$ & 0.76 & $96.2 \%$ & $85.7 \%$ & $<.0001$ \\
\hline Dorin in Firace & No & $8.4 \%$ & $7.8 \%$ & 0.10 & $3.9 \%$ & $14.3 \%$ & ..000 \\
\hline Living in the & No & $81.8 \%$ & $73.2 \%$ & & $85.3 \%$ & $78.8 \%$ & \\
\hline France) region & Yes & $18.2 \%$ & $26.8 \%$ & 0.01 & $14.7 \%$ & $21.2 \%$ & 0.03 \\
\hline
\end{tabular}


TABLE 2: factors associated with using more expensive cigarette brands (depict study, n=1379, 2016-2017): multivariable analysis

\begin{tabular}{|c|c|c|c|}
\hline \multirow{2}{*}{\multicolumn{2}{|c|}{ Characteristics }} & \multicolumn{2}{|c|}{ Adjusted Odds Ratio [95\% CI]a } \\
\hline & & \multirow{2}{*}{$\begin{array}{c}\text { Women } \\
0.87[0.62-1.21]\end{array}$} & \multirow{2}{*}{$\frac{\text { Men }}{1.03[0.74-1.43]}$} \\
\hline Year of investigation & 2017 vs. 2016 & & \\
\hline \multicolumn{4}{|c|}{ Tobacco and other substance use } \\
\hline $\begin{array}{c}\text { Number of cigarettes per } \\
\text { day }\end{array}$ & $\begin{array}{c}0-9 \mathrm{cig} / \mathrm{days} \text { vs. } \\
\text { cig/days }\end{array}$ & $1.45[1.04-2.02]$ & $1.14[0.78-1.67]$ \\
\hline \multirow[b]{2}{*}{$\begin{array}{c}\text { Household tobacco } \\
\text { exposure }\end{array}$} & $\begin{array}{l}\text { Non-smoking home vs. } \\
\text { Living alone }\end{array}$ & $1.15[0.78-1.71]$ & $1.83[1.24-2.72]$ \\
\hline & $\begin{array}{l}\text { Living with a smoker } \\
\text { (partner or other) vs. } \\
\text { Living alone }\end{array}$ & $1.06[0.72-1.55]$ & $1.16[0.78-1.71]$ \\
\hline $\begin{array}{c}\text { (At least occasional ) } \\
\text { smoking of roll-your-own } \\
\text { tobacco }\end{array}$ & No vs. Yes & $1.88[1.17-3.02]$ & $1.24[0.82-1.88]$ \\
\hline $\begin{array}{l}\text { Cannabis smoked in the } \\
\text { past } 12 \text { months }\end{array}$ & Yes vs. No & $3.03[1.69-5.42]$ & $1.54[0.98-2.42]$ \\
\hline \multicolumn{4}{|c|}{ Purchasing behaviors and perception of tobacco brand } \\
\hline $\begin{array}{c}\text { Cross-border purchase of } \\
\text { tobacco in the preceding } \\
\text { year }\end{array}$ & Yes vs. No & $0.78[0.56-1.09]$ & $1.28[0.91-1.8]$ \\
\hline $\begin{array}{c}\text { Attachment to tobacco } \\
\text { brand }\end{array}$ & Yes vs. No & $1.31[0.95-1.81]$ & $1.66[1.20-2.31]$ \\
\hline \multicolumn{4}{|c|}{ Sociodemographic characteristics } \\
\hline \multirow{2}{*}{ Age } & $18-24$ vs. $45-64$ & $0.95[0.55-1.64]$ & $3.81[2.05-7.09]$ \\
\hline & $25-44$ vs. $45-64$ & $1.47[1.03-2.10]$ & $1.91[1.34-2.71]$ \\
\hline \multirow[t]{2}{*}{ Education level } & $\begin{array}{c}\text { High school degree }- \\
\text { Bac }+2 \text { vs. }<\text { High } \\
\text { school degree }\end{array}$ & $2.00[1.38-2.89]$ & $0.95[0.66-1.37]$ \\
\hline & $\begin{array}{l}\geq \text { University degree vs. } \\
<\text { High school degree }\end{array}$ & $2.09[1.37-3.18]$ & $0.91[0.58-1.42]$ \\
\hline Born in France & No vs. Yes & $0.83[0.46-1.49]$ & $4.45[2.23-8.88]$ \\
\hline $\begin{array}{l}\text { Living in the Parisian } \\
\text { region }\end{array}$ & Yes vs. No & $1.48[1.00-2.19]$ & $1.36[0.86-2.13]$ \\
\hline
\end{tabular}

